\title{
Clinical Use of Polihexanide on Acute and Chronic Wounds for Antisepsis and Decontamination
}

\author{
T. Eberlein ${ }^{\mathrm{a}}$ O. Assadian ${ }^{\mathrm{b}}$ \\ ${ }^{a}$ Dermatologist/Allergologist, Palma, Spain; ${ }^{b}$ Institute of Hygiene and Environmental Medicine, \\ Ernst Moritz Arndt University Greifswald, Greifswald, Germany
}

\section{Key Words}

Polihexanide $\cdot$ Antisepsis · Decontamination • Wound

cleansing $\cdot$ Chronic wounds $\cdot$ Acute wounds

\begin{abstract}
Polihexanide is an antimicrobial compound suitable for clinical use in critically colonized or infected acute and chronic wounds. Its beneficial characteristic is attributable particularly to its broad antimicrobial spectrum, good cell and tissue tolerability, ability to bind to the organic matrix, low risk of contact sensitization, and wound healing promoting effect. In addition, no development of microorganism resistance during polihexanide use has been detected to date, nor does this risk appear imminent. The aim of therapy using polihexanide is to reduce the pathogen burden in a critically colonized or infected acute or chronic wound. An increasing number of articles on the subject of wound antisepsis with polihexanide can be found in the medical literature. However, there is still little published information on the practical use of polihexanide-containing wound antiseptics. The purpose of this review article is to describe the handling and the different possibilities of use of polihexanide-containing preparations, including the currently approved indications, contraindications and reservations. The use of polihexanide is not the only therapeutic option in management of
\end{abstract}

wounds; therefore, priority is also given to prior surgical debridement and clarification of the cause of the underlying disease, including appropriate therapy.

Copyright $\odot 2010$ S. Karger AG, Basel

\section{Background}

The term 'antisepsis' was first coined at the end of the 18th century by the English military physician John Pringle (1707-1782) to apply to substances that were able to prevent putrefaction [1]. With the continuation of antiseptic measures in surgery, Sir Joseph Lister (1827-1912) subsequently made the prevention of postoperative complications a central theme internationally in surgery [2].

Lister flushed surgical wounds with carbolic acid, and combined this procedure with dressings soaked in carbolic acid. Finally, he introduced the spray technique, in which the entire operation field was sprayed regularly with a carbolic acid spray. With the aid of these measures, the mortality rate after amputations and open bone fractures was reduced from $60 \%$ to less than $10 \%$ [3].

Later, however, the substance revealed its severe side effects resulting from systemic absorption with local tissue damage and general symptoms of toxicity. As a result, Billroth and Kocher formulated their famous warning

\section{KARGER}

Fax +4161306 1234

E-Mail karger@karger.ch

www.karger.com
(C) 2010 S. Karger AG, Basel

$1660-5527 / 10 / 0237-0045 \$ 26.00 / 0$

Accessible online at:

www.karger.com/spp
Ojan Assadian, MD, DTMH

Institute of Hygiene and Environmental Medicine

Ernst Moritz Arndt University Greifswald, Walther Rathenau Strasse 49a DE-17489 Greifswald (Germany)

Tel. +49 3834515 540, Fax +49 3834515 541, E-Mail assadian@ @ni-greifswald.de 
against the use of carbolic acid, although they questioned only the substance and not the prevention principle of antisepsis. In 1881, Kocher rehabilitated Lister, and described his ideas as an 'immortal service'. He accepted that prevention of wound infection could only have been established through Lister's pioneering work [4].

Thus, the preventive principle of wound antisepsis was born. However, the search continued for suitable substances that could be used safely. The procedure was also fundamentally improved technically. Alexis Carrel (18731944) extended simple wound irrigation and developed the specific, continuous or intermittent wound drainage [5].

In the following years, a wide variety of irrigation solutions were recommended, beginning with low-concentrated zinc-chlorine solutions (Kocher 1881), sublimate (Robert Koch 1883), iodoform (Billroth 1885), Dakin's (chlorine-containing) solution (Carrel 1917), azo dyes (Rivanol 1920s), and sulphonamides (1930s). This progress repeatedly bore fruit to some degree, but no truly satisfactory substance could be found. The main problems were not so much the antiseptic efficacy, but the side effects that occurred as a result of systemic absorption, and tissue toxicity that occurred repeatedly. For example, it was found in the case of the sulphonamides that formation of granulation tissue and thus wound healing overall is inhibited. With all the mentioned substances that were in use, the cases of postoperative wound infections were considerably reduced. Nevertheless, following the use of chlorine solutions, for example, up to $90 \%$ of the patients treated with these died after a few years [6].

The discovery of antibiotics led to the principles of wound antisepsis very quickly being forgotten. The previously constant search for new, suitable antiseptic substances was abruptly interrupted. The optimism induced by the possibilities of systemic antibiotic therapy led to rapidly increasing systemic and topical use of antibiotics. For some years now, we have been seeing the long-term consequence of this in the form of the increasing resistance of bacteria to antibiotics.

However, doubts were expressed at an early stage as to whether topical treatment with antibiotics could be justified. In 1961, the leading article in the Journal of Clinical Pathology stated: 'The administration of antibiotics, which often betrays a shocking lack of insight, has led to the occurrence of resistant bacteria among the banal bacteria. The return to the elementary principles of topical wound treatment and wound antisepsis is therefore what is called for' [7]. This assessment is still just as relevant today. As a result of these developments, we are now experiencing a comeback of antiseptics.
Willenegger and Good recognized the fundamental possibility of use of the surface disinfectant polihexanide, known in the industry since the 1960s, and characterized by its good bactericidal efficacy. They hit on the idea of adding polyethylene glycol to a biguanide (polihexanide) that was already known for surface disinfection and had a good bactericidal efficacy and no known toxicity [8]. The antimicrobial mechanism of action of polihexanide was clarified [9, 10; Kaehn et al., this supplement issue]. The work published by Werner [11] finally led to the recognition of this substance as a wound antiseptic in Central Europe. Thus, a surface disinfectant and swimming pool disinfectant, unsuitable for use in a wound, became a polihexanide-containing solution for wound antisepsis. This topical anti-infective agent exhibited a hitherto unknown therapeutic margin [12], and in 1994 Switzerland was the first country in the world to approve it as a medicinal product.

The characteristics of polihexanide are comprehensively described in another article in this supplement [Hübner and Kramer, this supplement issue]. The first randomized controlled trial was conducted by SchmitNeuerburg et al. $[13,14]$. They studied the effect of gauze compresses soaked in $0.04 \%$ polihexanide in comparison with Ringer solution in a randomized, controlled, double-blind study in 85 patients. The group treated with polihexanide showed improved wound healing with a significantly more rapid reduction of Gram-positive organisms and also better tissue compatibility than was the case in the control group.

By far the most extensive collection of data on the use of polihexanide-containing external preparations is presented by Roth et al. [15]. These data from a retrospective, open-label, controlled, multicentre, randomized cohort study involving 7,862 patients, mainly with agricultural, severe and contaminated soft-tissue injuries, compare the rate of postoperative wound infections with polihexanide, PVP-iodine, Ringer solution and hydrogen peroxide after only a single antiseptic irrigation with prior thorough surgical debridement (irrespective of whether the wound was primarily closed or had to be left partially open or completely open). With the use of polihexanide, the infection rate could be significantly reduced in comparison to PVPiodine, Ringer solution and hydrogen peroxide.

Although there are an increasing number of articles on the subject of wound antisepsis with polihexanide in the medical literature, there is little detailed information on the use of polihexanide-containing wound antiseptics in practice. The purpose of this review article is to describe the handling and the different possibilities of use 
Table 1. BI for selected antiseptic substances after 30 min contact in MEM cell culture medium in the presence of $10 \%$ fetal bovine serum [30]

\begin{tabular}{|c|c|c|}
\hline \multirow[t]{2}{*}{ Substance } & \multicolumn{2}{|l|}{ BI } \\
\hline & $\begin{array}{l}\text { L929 cells/ } \\
<\text { E. coli }\end{array}$ & $\begin{array}{l}\text { L929 cells/ } \\
\text { S. aureus }\end{array}$ \\
\hline Octenidine dihydrochloride & 1.8 & 1.5 \\
\hline Polihexanide & 1.5 & 1.3 \\
\hline PVP-iodine (referring to $\mathrm{I}_{2}$ ) & 1.0 & 0.9 \\
\hline Chlorhexidine digluconate & 0.8 & 0.7 \\
\hline Silver protein (referring to $\mathrm{Ag}$ ) & 0.13 & - \\
\hline Silver sulphadiazine & $<<0.004$ & - \\
\hline $\mathrm{AgNO}_{3}$ & $<<0.002$ & - \\
\hline
\end{tabular}

$\mathrm{BI}=$ Biocompatibility index.

of polihexanide-containing preparations, including the currently approved indications, contraindications and reservations.

\section{Properties of Polihexanide-Containing Preparations}

Relevant for the Treatment of Wounds

Depending on the concentration and application form, there are various advantages for polihexanide that in view of efficacy and tolerability predestine the substance for use in critically colonized as well as locally infected acute and chronic wounds. In addition to its simplicity of use, these advantages also include the following:

- broad antimicrobial spectrum [13, 14, 16-19, 21-24, 29];

- sustained and post-antiseptic effect $[19,20]$;

- concentration-dependent promotion of wound healing in vitro und in vivo [21-27];

- specific mechanism of action against acidic lipids of the bacterial membrane with an only slight effect on the neutral lipids in human cell membranes [28];

- favourable biocompatibility index $(\mathrm{BI})>1$ [29]. For comparison of the tolerability of wound antiseptics, the $\mathrm{BI}$ is suitable [30]. A condition of this is that the testing for microbicides and cytotoxicity must be carried out under identical test conditions. Cell culture media with a protein content of 6-7 g/l serum albumin and a physiological electrolyte concentration are largely equivalent in composition to the protein and electrolyte contents of wound fluids. The BI is obtained from the quotient of $\mathrm{IC}_{50}$, i.e. the molar concentration at which $50 \%$ of the test cells in the cytotoxicity test are no longer vital, and the molar concentration that in the quantitative suspension test against bacterial test microorganisms results in a reduction of at least $3 \mathrm{log}$ steps. The BI is thus a dimensionless figure and permits a comparison of tolerability. A value $>1$ describes good tolerability, a value $<1$ poor microbicidal efficacy, combined with high cytotoxicity. In table $1, \mathrm{BIs}$ for selected antiseptic substances for the system mouse fibroblasts (L929 cells, ATCC CCL1)/Escherichia coli (ATCC 11229) and Staphylococcus aureus (ATCC 6538) are given;

- no known toxic and absorptive risks [19];

- to date, no known development of resistance [19, 31];

- reduction of biofilm [32-34] and fibrin formation [3537];

- good clinical tolerability [17, 38-41];

- additional anti-inflammatory properties [42];

- low risk of contact sensitizations as well as of type I sensitizations [19, 43-46].

\section{Contraindications}

With the present level of knowledge, polihexanide may not be used in the following indications or situations $[19,47]$ :

- as an irrigation solution in the peritoneal cavity;

- as an antiseptic joint irrigation solution in the use concentration recommended by the manufacturer (hyaline cartilage toxicity);

- in the entire central nervous system including the meninges and intralumbarly;

- in the middle ear or inner ear or intraocularly;

- in the first 4 months of a pregnancy (later only after critical evaluation of the benefit/risk ratio);

- in cases of allergy to polihexanide.

\section{Overview of Available Polihexanide Application}

\section{Forms}

Worldwide there are now a large number of polihexanide-containing products on the market. These include antiseptic solutions, wound irrigation solutions, hydrogels and wound dressings. Tables $2-5$ give an overview of polihexanide application forms currently available on the world market, although they are subject to considerable national differences.

As a result of regulatory intricacies that can only be understood by the legal profession, there is currently a marketing authorization situation that is in some cases confusing, so that even identical products are classified differently, e.g. Lavasorb ${ }^{\circledR}$ (in Switzerland, Germany and Austria: a class IIb medical device) and Lavasept ${ }^{\circledR}$ (in Switzerland: a medicinal product). 
Table 2. Wound antiseptics containing polihexanide and given medicinal product status

\begin{tabular}{lclll}
\hline Product & $\begin{array}{l}\text { Polihexanide } \\
\text { concentration, \% }\end{array}$ & Excipients & Manufacturer & Available in \\
\hline Lavasept ${ }^{\circledR}$ concentrate & 20.0 & Macrogol 4000, Ringer's solution & B. Braun & Germany, Russia, Switzerland \\
Lavasept ${ }^{\circledR}$ solution & 0.04 & Macrogol 4000, Ringer's solution & B. Braun & Switzerland \\
Serasept ${ }^{\circledR}$ solution 1 & 0.02 & Macrogol 4000, Ringer's solution & Serag-Wiesner & Germany \\
Serasept ${ }^{\circledR}$ solution 2 & 0.04 & & & \\
\hline
\end{tabular}

Table 3. Wound irrigation solutions/wound cleansers containing polihexanide and given medical device status

\begin{tabular}{|c|c|c|c|c|}
\hline Lavasorb $^{\circledR}$ solution & 0.04 & Macrogol 4000, Ringer's solution & Fresenius & EU \\
\hline $\begin{array}{l}\text { Lavanid }^{\circledR} \text { solution } 1 \\
\text { Lavanid }^{\circledR} \text { solution } 2\end{array}$ & $\begin{array}{l}0.02 \\
0.04\end{array}$ & Macrogol 4000, Ringer's solution & Serag-Wiesner & $\mathrm{EU}$ \\
\hline
\end{tabular}

Table 4. Hydrogels containing polihexanide for wound cleansing (medical devices)

\begin{tabular}{|c|c|c|c|c|}
\hline $\begin{array}{l}\text { Lavanid }^{\circledR} \\
\text { wound gel }\end{array}$ & 0.04 & $\begin{array}{l}\text { Macrogol, glycerin, hydroxyethyl } \\
\text { celluloses, Ringer's solution }\end{array}$ & Serag-Wiesner & $\mathrm{EU}$ \\
\hline $\begin{array}{l}\text { Prontosan }^{\circledR} \\
\text { wound gel }\end{array}$ & 0.1 & $\begin{array}{l}\text { Undecylenamidopropyl betaine } \\
\text { (surfactant), glycerol, hydroxyethyl } \\
\text { celluloses }\end{array}$ & B. Braun & $\begin{array}{l}\text { Australia, Brazil, Canada, Chile, Croatia, } \\
\text { EU, Hong Kong, Israel, Malaysia, Norway, } \\
\text { Peru, Russia, Serbia, South Africa, Switzer- } \\
\text { land, Thailand, Turkey, USA }\end{array}$ \\
\hline
\end{tabular}

In clinical practice, the usually applied concentrations of polihexanide solutions for wound antisepsis are 0.01 , 0.02 and $0.04 \%$. In addition, wound irrigation solutions or polihexanide-containing dressings show concentrations of $0.1-0.5 \%$. In the case of a new biocellulose moist dressing with a concentration of $0.3 \%$ polihexanide in the fibres, in in vitro studies the release of active substance in steady state is approximately $0.13 \%$ [48]. The products are only to be used topically, for example in the form of irrigations (lavages), irrigation-suction drains as well as moist wound coverings. As polihexanide has a relatively slow onset of effect, and the microorganisms react with different sensitivity as a function of time, it must be ensured that with full coverage of the wound base a minimum contact time of $10-15 \mathrm{~min}$ is adhered to $[19,49]$. Its use may be based on therapeutic indication, but also for prophylactic reasons.

\section{Special Aspects of Practical Use}

Starting Point of Therapy

Precisely with regard to the microbial condition, acute and chronic wounds can change dramatically within a 
Table 5. Wound dressings containing polihexanide (medical devices)

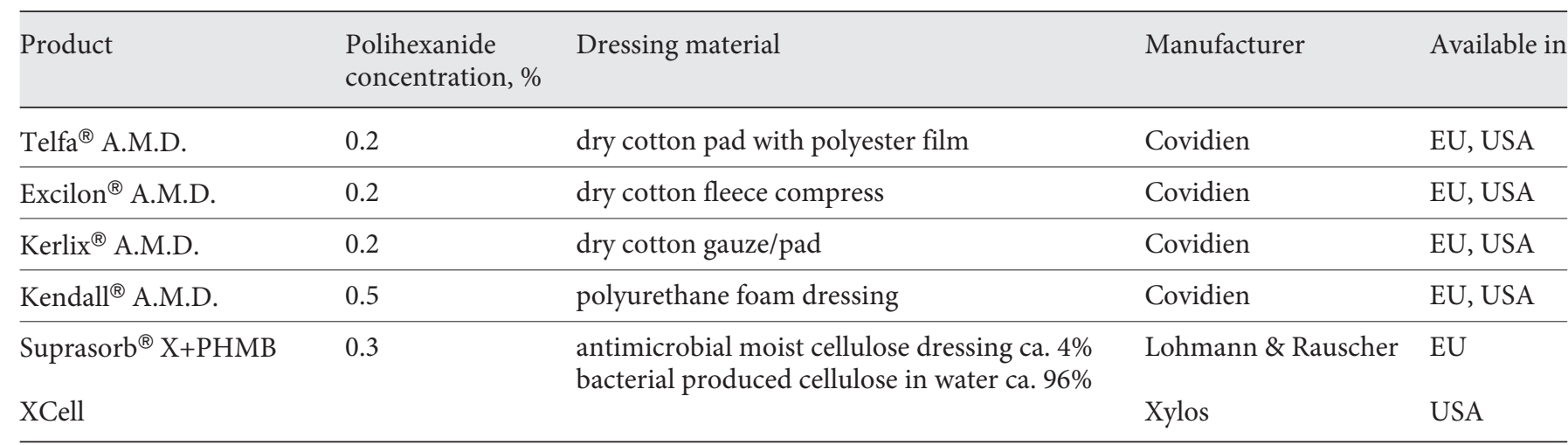

Table 6. Procedure of the practical application of intra-operative irrigation

(1) Positioning of drain with infection or risk for infection after surgical cleansing

(2) Beginning of irrigation

(3) Flushing of still putrid exudate from the drain

(4) Completion of the irrigation with clean conditions

(5) Application of the dressing

short time. In such a case, it is crucial for the success of treatment that adequate therapy is initiated without delay. Therapy is indicated from the stage of critical colonization. Critical colonization is a state of transition from colonization (frequent in the case of secondarily healing wounds) to infection. By means of specific topical antimicrobial therapy the transition into a wound infection can often be prevented [50]. Antisepsis can only support wound cleansing, it can never replace it.

Duration of Treatment and Endpoint of Antiseptic

Therapy and Prophylaxis

The prime objective of the treatment is to eliminate the clinical signs of infection. The duration of topical antiseptic treatment is usually $2-5$ days, and in general should not exceed $14-21$ days $[51,52]$. If the signs of infection do not recede, the efficacy of the measures used must be checked, and if necessary new measures must be initiated. If therapy is successful, treatment must be continued according to the general principles of moist wound treatment, but without the addition of an antimicrobial preparation.

This approach is based on the consideration that the use of previous antiseptics whose antimicrobial efficacy is necessarily always accompanied by some degree of cytotoxicity is only justified if a microbial burden that is affecting the course of wound healing is present. In this case, on the basis of the risk/benefit consideration, the risk of an infection must be judged higher than the risk of cytotoxicity. With polihexanide, however, we have a wound antiseptic that is favourable with regard to both antimicrobial effect and cytotoxicity and with a correspondingly high $\mathrm{BI}$, thus permitting a different evaluation of the benefit/risk ratio. Although, purely theoretically, consideration should therefore be given as to whether, in the case of use of polihexanide-containing products, preventive continuation of the antiseptic treatment would indeed be possible under certain circumstances, a definitive statement cannot be made without the existence of further experimental and clinical data. In any case, financial considerations support the discontinuation of antiseptic therapy when the infection has been controlled. The exceptions to the continuation of antiseptic treatment after the completion of therapy are patients in whom, on account of their health or sociohygienic situation, recontamination with pathogenic organisms is very likely. In this case, the antiseptic therapy passes seamlessly into preventive antiseptic treatment.

Polihexanide is also suitable for primary preventive use. At the present time, however, there are few data available [15]. Whether preventive use is indicated must always be evaluated critically in the individual benefit/risk analysis and from the therapeutic and financial aspects, 
and must be repeatedly reviewed. Non-specific, unjustified and permanent use must be refused.

\section{Practical Application}

In wound treatment, classic moist dressings and wet compresses during dressing changes are good clinical practice. In this context, depending on the indication, various polihexanide-containing preparations or dressings may be used.

Application may take place in the form of use of an antiseptic, a wound irrigation solution or gel, or also in the form of a wound covering. The example of a typical procedure for such a dressing is described in table 6 [53].

\section{Conclusion}

Polihexanide is an antimicrobial substance that is highly suitable for use in critically colonized or infected acute and chronic wounds. Its positive evaluation is attributable particularly to its broad antimicrobial spectrum, good cell and tissue tolerability, ability to bind to the organic matrix, low risk of contact sensitization, and wound healing promoting effect. In addition, no development of microorganism resistance during polihexanide use has been detected to date, nor does this risk appear imminent.

The aim of therapy with polihexanide is to reduce the pathogen burden in a critically colonized or infected acute or chronic wound. The use of polihexanide is not the only therapy option; priority is given to prior surgical debridement and clarification of the cause of the underlying disease, including appropriate therapy.

\section{Disclosure Statement}

The authors declare that they have no patents or patents pending for any of the medical devices, and no stocks or stocks options related to any company manufacturing commercially available products on the basis of polihexanide as the active antimicrobial ingredient. Dr. Thomas Eberlein declares having received financial support as a clinical investigator and speaker for B. Braun, Lohmann \& Rauscher, and Prontomed. Professor Ojan Assadian received speaker's honoraria for public medical education related to clinical use of antiseptics, including polihexanide, in the past from B. Braun and Lohmann \& Rauscher.

\section{References}

1 Pringle J: Observations on the Diseases of the Army, ed 4 revised. London, Millar, Wilson, Durham, Payne, 1764.

2 Lister J: Amputation, anaesthetics; in Holmes T (ed): A System of Surgery, Theoretical and Practical. London, Robson, Levey, and Franklin, 1860, vol 3: Operative Surgery.

-3 Lister J: On the antiseptic principle on the practice of surgery. Lancet 1867;90:353-356.

4 Kocher T: Die antiseptische Wundbehandlung mit schwachen Chlorzinklösungen in der Berner Klinik; in Volksmanjn R (ed): Sammlung klinischer Vorträge. Leipzig, Breitkopf und Härtel, 1881.

5 Carrel A, Lecomte Du Noüy P, Carrel A: Cicatrization of wounds. 9. Influence on the healing of wounds of variations in the osmotic tension of the dressing. J Exp Med 1917;26:279-295.

6 Lister J: An address on the present position of antiseptic surgery. BMJ 1890;1546:377379.

7 Gillespie WA: Chemical disinfection in the prevention of infection in hospital. J Clin Pathol 1961;14:26-31.

$\checkmark 8$ Willenegger $\mathrm{H}$, Roth B, Ochsner P: The return of local antiseptics in surgery. Injury 1995;26:28-33.
9 Davies A, Field BS: Action of biguanides, phenols and detergents on Escherichia coli and its spheroplasts. J Appl Bact 1969;23: 233-243.

10 Ikeda T, Tazuke S, Watanabe M: Interaction of biologically active molecules with phospholipid membranes. Fluorescence depolarisation studies on the effect of polymeric biocide bearing biguanides in the main chain. Biochim Biophys Acta 1983;735:380-386.

11 Werner HP: Microbicidal effectiveness of selected antiseptics. Hyg Med 1992;17:51-59.

12 Kramer A, Adrian V, Werner HP: Mikrobizidie und Gewebeverträglichkeit des Antiinfektivums Lavasept ${ }^{\circledR}$ mit Schlussfolgerungen für die Indikationbreite; in Ganzer D, Kramer A, Mayer G (eds): Prophylaxe und Therapie von Infektionen in der Orthopädie. Wiesbaden, mhp, 1997, pp 11-26.

13 Schmit-Neuerburg K, Bettag C, Schlickewei W, Fabry W, Hanke J, Renzig-Köhler K, Hirche H, Kock HJ: Wirksamkeit eines neuartigen Antisepticum in der Behandlung kontaminierter Weichteilwunden. Chirurg 2001;72:61-71

14 Fabry W, Trampenau C, Bettag C, Handschin AE, Lettgen B, Huber FX, Hillmeier J, Kock AJ: Bacteria decontamination of surgical wounds with Lavasept ${ }^{\circledR}$. Int J Hyg Environ Health 2006;209:567-573.
15 Roth B, Assadian O, Wurmitzer F, Kramer A: Surgical site infections after primary antiseptic cleansing of dirty-contaminated wounds by polihexanide, PVP iodine resp. hydrogen peroxide. GMS Krankenhaushyg Interdiszip 2007;2:Doc58(20071228).

16 Müller G, Kramer A: Biocompatibility index of antiseptic agents by parallel assessment of antimicrobial activity and cellular cytotoxicity. J Antimicrob Chemother 2008;61: 1281-1287.

17 Disch AC, Matziolis G, Perka C: Two-stage operative strategy without local antibiotic treatment for infected hip arthroplasty: clinical and radiological outcome. Arch Orthop Trauma Surg 2007;127:691-697.

18 Schmidtchen A, Davoudi M, Andersson E: Potent antibacterial effects of polyhexamethylene biguanide on common chronic ulcer-derived bacteria. Annu Conf EWMA, Pisa, 2003.

19 Kramer A, Roth B: Polihexanid; in Kramer A, Assadian O (eds): Wallhäussers Praxis der Sterilisation, Desinfektion, Antiseptik und Konservierung. Stuttgart, Thieme, 2008, pp 789-793. 
-20 Rosin M, Welk A, Kocher T, Majic-Todt A, Kramer A, Pitten FA: The effect of a polyhexamethylene biguanide mouthrinse compared to an essential oil rinse and a chlorhexidine rinse on bacterial counts and 4-day plaque regrowth. J Clin Periodontol 2002;29: 392-399.

21 Wiegand C, Abel M, Kramer A, Müller G, Ruth P, Hipler UC: Viability and proliferation of fibroblasts, keratinocytes and HaCaT-cells influenced by polihexanide. EWMA J;7:109.

22 Wiegand C, Abel M, Ruth P, Hipler U: Protective effect of polihexanide on HaCaT keratinocytes in co-culture with Staphylococcus aureus. EWMA J 2008;8:178.

-23 Kramer A, Roth B, Muller G, Rudolph P, Klocker N: Influence of the antiseptic agents polihexanide and octenidine on FL-cells and on healing of experimental superficial aseptic wounds in piglets. A double-blind, randomised, stratified, controlled, parallelgroup study. Skin Pharmacol Physiol 2004. 17:141-146.

24 Daeschlein G, Assadian O, Bruck JC, Meinl C, Kramer A, Koch S: Feasibility and clinical applicability of polihexanide for treatment of second-degree burn wounds. Skin Pharmacol Physiol 2007;20:292-296.

25 Bolton L, Oleniacz W, Constantine B, Kelliher BO, Jensen D, Means B, Rovee D: Repair and antibacterial effects of topical antiseptic agents in vivo; in Maibach Hl, Lowe NJ (eds): Models in Dermatology. Basel, Karger, 1985, pp 145-158.

26 Kallenberger A, Kallenberger C, Willenegger H: Experimentelle Untersuchungen zur Gewebeverträglichkeit von Antiseptika. Hyg Med 1991;16:383-395.

27 Andriessen A, Eberlein T: Assessment of a wound cleansing solution in the treatment of problem wounds. Wounds 2008;20:171-175.

28 Ikeda T, Tazuke S, Watanabe M: Interaction of biologically active molecules with phospholipid membranes. 1. Fluorescence depolarization studies on the effect of polymeric biocide bearing biguanide groups in the main chain. Biochim Biophys Acta 1983;735: 380-386.

-29 Müller G, Kramer A: Biocompatibility index of antiseptic agents by parallel assessment of antimicrobial activity and cellular cytotoxicity. J Antimicrob Chemother 2008;61: 1281-1287.
30 Assadian O, Kramer A: Antisepsis; in Kramer A, Assadian O (eds): Wallhäussers Praxis der Sterilisation, Desinfektion, Antiseptik und Konservierung. Stuttgart, Thieme, 2008.

31 Gilbert P, Moore LE: Cationic antiseptics: diversity of action under a common epithet. J Appl Microbiol 2005;99:703-715.

32 Pietsch M, Kraft B: Antimikrobielle Wirksamkeit ausgewählter Substanzen für die Wasserdesinfektion in Dentaleinheiten mit Biofilm. Aseptica 2006;12:3.

33 Harbs N, Siebert J: In vitro efficacy of octenidine and polihexanide against biofilms composed of Pseudomonas aeruginosa. GMS Krankenhaushyg Interdiszip 2007; 2:Doc45(20071228)

34 Seipp HM, Hofmann S, Hack A, Skowronsky A, Hauri A: Wirksamkeit verschiedener Wundspüllösungen gegenüber Biofilmen. ZfW 2005;10:160-164.

35 Daeschlein G, Assadian O, Bruck JC, Meinl C, Kramer A, Koch S: Feasibility and clinical applicability of polihexanide for treatment of second-degree burn wounds. Skin Pharmacol Physiol 2007;20:292-296.

36 Körber A, Seipp H-M, Hofmann S: Efficacy of different wound dressings on artificial plaques of fibrin. EWMA J 2008;8:261.

37 Kaehn K, Eberlein T: Polyhexanide (PHMB) and betaine in wound care management. EWMA J 2008;8:13-17.

38 Mulder GD, Cavorsi JP, Lee DK: Feature: Polyhexamethylene biguanide (PHMB): an addendum to current topical antimicrobials. Wounds 2007;19:173-182.

39 Bruckner M, Schwarz C, Otto F, Heillinger J, Wild T: Evaluation of cellulose and polyhexamethylene biguanide (Suprasorb $^{\circledR}$ $\mathrm{X}+\mathrm{PHMB})$ in therapy of infected wounds. EWMA J 2008;8:54.

40 Mosti G, Mattaliano V: First Italian experience with a hydrobalanced cellulose-based wound dressing on hospital-patients with critically-colonized or locally infected chronic wounds. Poster. EWMA J 2008;8: 168.

41 Mosti G, Mattaliano V: Successful therapy of critically-colonised or locally infected wounds with a new hydrobalanced cellulosebased wound dressing with polihexanide on out-patients. EWMA J 2008;8:169.

42 Wiegand C, Abel M, Ruth P, Hipler UC: Polihexanide inhibits the formation of ROS/RNS in vitro. EWMA J 2008:8:178.

-43 Schnuch A, Geier J, Uter W, Basketter DA, Jowsey IR: The biocide polyhexamethylene biguanide remains an uncommon contact allergen. Contact Dermatitis 2007;56:235239.
4 Schnuch A, Geier J, Brasch J, Fuchs T, Pirker C, Schulze-Dirks A, Basketter DA: Polyhexamethylenebiguanide: a relevant contact allergen? Contact Dermatitis 2000;42:302303.

45 Freise J, Kohaus S, Korber A, Hillen U, Kroger K, Grabbe S, Dissemond J: Contact sensitization in patients with chronic wounds: results of a prospective investigation. J Eur Acad Dermatol Venereol 2008;22: 1203-1207.

46 Krautheim AB, Jermann TH, Bircher AJ: Chlorhexidine anaphylaxis: case report and review of the literature. Contact Dermatitis 2004;50:113-116.

47 Deutscher Arzneimittel-Codex DAC/Neues Rezeptur-Formularium NRF. Eschborn, Govi, 2008.

48 Wilhelms T, Schulze D, Alupei IC, Rohrer C, Abel M, Wiegand C, Hipler UC: Release of polyhexamethylene biguanidine hydrochloride (PHMB) from a hydrobalanced cellulose wound dressing with PHMB. EWMA J 2007; 7:113.

49 Werner H, Kramer A: Mikrobiologische Anforderungen an lokale Antiinfektiva unter spezieller Berücksichtigung der antiinfektiven Wundbehandlung; in Kramer A, Wendt M, Werner H-P (eds): Möglichkeiten und Perspektiven der klinischen Antiseptik. Wiesbaden, mhp, 1995, pp 26-30.

50 European Wound Management Association (EWMA): Position Document: Identifying Criteria for Wound Infection. London, MEP Ltd, 2005, pp 1-17.

51 Dissemond J, Gerber V, Kramer A, Riepe G, Strohal R, Vasel-Biergans A, Eberlein T: Practice-oriented expert recommendation for the treatment of critically colonised and locally infected wounds using polihexanide. ZfW 2009;14:20-26.

52 Dissemond J, Gerber V, Kramer A, Riepe G, Strohal R, Vasel-Biergans A, Eberlein T: A practice-orientated recommendation for treatment of critically colonized and locally infected wounds using polihexanide. J Wound Tech 2010;7:27-33.

-53 Kammerlander G, Andriessen A, Asmussen P D, Brunner U, Eberlein T: Role of the wetto-dry phase of cleansing in preparing the chronic wound bed for dressing application. J Wound Care 2005;14:349-352. 